\title{
Gammarids in Lake Constance: habitat segregation between the invasive Dikerogammarus villosus and the indigenous Gammarus roeselii
}

\author{
John Hesselschwerdt*, Jasmin Necker and Karl Matthias Wantzen ${ }^{1}$
}

With 3 figures and 2 tables

\begin{abstract}
Over the past decades the invasive Ponto-Caspian gammarid Dikerogammarus villosus spread throughout large rivers of central Europe, thereby rapidly displacing most of the native gammarid species. In 2003, D. villosus was first observed in Lake Constance and was predicted to out-compete the native Gammarus roeselii. However, today the two species coexist at several sites. We hypothesized that a higher variability of substrates in the littoral zone of Lake Constance, compared to that found in most European waterways, allows coexistence of these two species. To analyze substrate choice of these two gammarid species we exposed them individually and together in enclosures to the littoral zone in the lake. These enclosures contained a combination of the following substrates: bare stones, stones covered with Dreissena polymorpha, Chara sp., shells of Corbicula fluminea, leaves, and sand. D. villosus strongly preferred structure-rich hard substrates like stones while avoiding sand and leaf litter. G. roeselii barely differentiated among substrates occupying even sandy habitats. To compare these results with natural gammarid habitat choice we measured gammarid densities on the substrates mentioned above in the littoral zone of Lake Constance. In contrast to enclosures, G. roeselii was virtually displaced by $D$. villosus on stones covered with D. polymorpha in the lake. Even four years after the invasion of D. villosus, high densities of G. roeselii could still be found in Chara and leaf litter. From these data we hypothesize that G. roeselii takes refuge from D. villosus by colonizing substrates not occupied by the invader. These substrate types only exist in natural waterbodies and are lacking in regulated rivers which generally have poor substrate richness.
\end{abstract}

Key words: amphipoda, characea, crustacea, Dreissena, habitat choice, preference, structural diversity.

\section{Introduction}

Biological invasions are considered to be a major driving force behind changes in freshwater biodiversity (Sala et al. 2000). This is also true for the benthic communities of European rivers, which have, over the past three decades experienced a major shift in species caused by the invasion of exotic invertebrates (Bollache et al. 2004, Kelleher et al. 1998, Kinzelbach 1995).

Gammarids belong to the most successful aquatic invaders. To date they account for $80-90 \%$ of the macroinvertebrate numbers as well as biomass in the Rhine
River (van Riel et al. 2006). Reasons behind their success lie in: their high tolerance for a wide range of environmental conditions (Bruijs et al. 2001, Devin \& Beisel 2007, Wijnhoven et al. 2003), their high reproductive capacity (Devin et al. 2004, Pöckl 2007), and their superior competitiveness as predators (Dick et al. 1990, MacNeil \& Platvoet 2005). Nevertheless, spatial as well as temporal partitioning of resources and habitats may facilitate coexistence between native and invasive gammarid species (MacNeil et al. 2001), especially when organic substrates such as macrophytes or mussels present themselves as habitats for amphipods (Musko 1989, Zytkowicz 2008).

\footnotetext{
${ }^{1}$ Authors' address: Limnological Institute, University of Konstanz, Mainaustr. 252, 78464 Konstanz, Germany.

* Corresponding author; e-mail: John.Hesselschwerdt@web.de 
The Ponto-Caspian gammarid Dikerogammarus villosus (Sowinsky) arrived in Germany in 1992 via the Danube River. Thereafter, it rapidly spread throughout the Main and Rhine River System by passing through the recently completed Main-Danube Channel (Bij de Vaate et al. 2002, Tittizer et al. 2000). D. villosus is now well established in many waterways in Western and Middle Europe (Casellato et al. 2006, Bij de Vaate et al. 2002, Devin et al. 2001, Grabowski et al. 2007b). There, it often displaces native amphipods, thereby becoming the dominant amphipod species (Bollache et al. 2004, Dick \& Platvoet 2000, van Riel et al. 2006) while also out-competing non-crustacean invertebrate taxa (Haas et al. 2002). This fast expansion has been attributed to its high reproductive potential (Pöckl 2007, Grabowski et al. 2007a), its ability to disperse by attaching to boats and in ballast water (Bruijs et al. 2001), and due to its predation on other gammarid species (Dick et al. 2002, Kinzler \& Maier 2003).

D. villosus and D. haemobaphes (Eichwald) were also able to invade large European lakes. They displaced the earlier occurring Gammarus roeselii Gervais in Lake Balaton, Hungary in the 1950s (Musko 1994). In Lake Markermeer and Lake IJsselmeer D. villosus rapidly replaced the native gammarids (Dick \& Platvoet 2000). Lake Geneva, Switzerland/ France, and Lake Garda in Italy were also recently invaded (Bollache 2004, Casellato et al. 2006), but presently little is known as to whether or not the benthic community was affected in the latter cases.

In 2003, D. villosus was discovered in Lake Constance (Mürle et al. 2004) where it has quickly out-competed the previously dominant gammarid G. roeselii. G. roeselii originated from the Balkan area (Jazdzewski 1980). By 1835 it had been discovered and described in the surrounding waters of Paris (Gervais 1835 ) and is now considered a naturalized species in Central Europe ("it is a former exotic species, well established and in balance with its environment") (Josens et al. 2005).

Within a few months after the arrival of D. villosus, the abundance of $G$. roeselii on stony substrates rapidly declined (Mörtl et al. 2005). However, healthy populations of $G$. roeselii can still be found in stony habitats during the winter (own observations) in areas that $D$. villosus is known to occupy since the summer of 2003 (Mörtl et al. 2005). From spring to fall the area in the deeper littoral consists of sand overgrown by characeans. During the summers of 2005-2007 G. roeselii was predominantly observed in the characeans (1-2.5 $\mathrm{m}$ depth) with occasional sightings on stones ( $0-1 \mathrm{~m}$ depth). We therefore conclude that both species coexist in Lake Constance.

In comparison to the strongly anthropomorphic affected navigable parts of European waterways, the littoral zone of Lake Constance is characterized by a huge variety of natural substrates, inorganic ones ranging from silt to rock, including all particle sizes, several macrophyte species, and organic detritus in the form of leaf litter (Gross et al. 2002, Schmieder et al. 2004). Channelization of rivers often results in loss of habitat and diversity through replacement of variable substrate with more uniform sand or gravel streambeds and groyne packages along the riverbanks, e.g. in the Rhine River (Uehlinger et al., in press). We hypothesized that the coexistence of gammarid species results from substrate diversity, where suitable habitat for G. roeselii may be unfavorable for D. villosus. Distribution of gammarids in different habitats has mostly been assessed in the field (Devin et al. 2003, Mörtl et al. 2005, van Riel et al. 2006, Zytkowicz et al. 2008). But habitat choice is also affected by other factors including competition with other species and predation. To determine if gammarid distribution in the field is due to biological interactions rather than substrate choice, specific habitat choice experiments should be conducted. Until now such experiments were only carried out using lava stones and sand as substrates (van Riel et al. 2007). These experiments are transferable to artificially reconstructed rivers, but are not complex enough to be used in predicting habitat use for structure-rich lakes. To obtain more specific data we assessed substrate preference of D. villosus and $G$. roeselii individually and together in enclosures with six different substrates in the littoral zone of Lake Constance. Natural distributions for both gammarid species on varying substrates in the littoral of the lake were compared.

\section{Material and methods}

\section{Substrate preference enclosure experiments}

Individuals of D. villosus and G. roeselii were collected every two weeks from March to June 2006 in the littoral zone of Lake Constance near the city of Konstanz, Germany. Collected gammarids were kept in 20-1 flow-through systems flushed with filtered lake water $(40 \mu \mathrm{m})$, and were fed every second day with TetraMin ${ }^{\circledR}$ flakes. All substrates except leaves were taken from the littoral zone and thoroughly cleaned. Naturally abscised leaves of beech and poplar were collected in nets in the autumn of 2005 and air dried. The leaves of these tree species serve as adequate substrates for gammarid colonization (Pabst et al.2008). 
Enclosure experiments were carried out from March to July 2006 in the littoral zone of Lake Constance near the Limnological Institute [see Mörtl \& Rothhaupt (2003) for a detailed description of the study site]. There the lake banks incline gently and are covered with sand, pebbles, and gravel $(20-200 \mathrm{~mm}$ diameter). We tested habitat preference of gammarids in a twochoice setup by exposing cages containing two different substrates. The cages were made of an aluminum frame $(0.6 \times 0.4$ $\times 0.4 \mathrm{~m})$ covered with gauze $(1 \mathrm{~mm}$ mesh width). The cages had a removable aluminum partition wall, which allowed us to separate both half-sides of the cage for the counting of individuals on any given substrate combination at the end of the experiment. The gammarids were exposed to the cages for $72 \mathrm{~h}$ at a depth of $1.5 \mathrm{~m}$. After each cycle the cages were carefully lifted to the water surface to insert the partition walls from the top of the cage.

We tested gammarid substrate preference on six different substrates representing the naturally occurring substrates in Lake Constance including: 1) round stones of ca. $100 \mathrm{~mm}$ diameter $(\mathrm{n}=11), 2)$ round stones $(\mathrm{n}=9)$ covered with Dreissena polymorpha (Bivalvia) (13 $\pm 3 \mathrm{~mm}), 3$ ) a 30 - $\mathrm{mm}$ layer of cleaned Chara sp. (Macroalgae) $(7.3 \pm 1.2 \mathrm{~g}$ dry wt.), 4) 210 empty Corbicula fluminea (Bivalvia) shells arising from 105 individuals $(15.7 \pm 2.7 \mathrm{~mm}), 5)$ leaves of beech $(3.2 \mathrm{~g}$ dry wt. $)$ and poplar (2.0 g dry wt.), and 6) a 2-mm layer of sand $(<0.2 \mathrm{~mm}$ grain size). These substrates were all placed on top of $2 \mathrm{~mm}$ of sand. Biases arising from currents along the shore were circumvented by orienting replicate cages in opposite directions.

During the experimental period the mean daily water temperature rose gradually from $6.2{ }^{\circ} \mathrm{C}$ in March to $24.5^{\circ} \mathrm{C}$ in June. Effects of changing water temperatures were minimized by evenly distributing the replicates during the experimental period (spring to summer): two replicates each at the beginning, middle, and end of the experimental period. Because the macroalgae Chara begins to grow in May, experiments with Chara were run then. Eight of the 162 samples were lost due to storms or vandalism which accounts for sample sizes of less than six.

\section{Stones as reference}

Bare stones were used as a benchmark for substrate preference. This benchmark applies to both species and during preliminary experiments in summer 2005, D. villosus intermittently preferred stones. We tested 6 combinations of two substrates in: each case bare stones versus one of the previously described substrates. G. roeselii and D. villosus were tested either as sin- gle species (32 individuals) in the enclosures or as mixed species (16 individuals of each species). This setup allowed for detection of habitat shifts caused by interspecific interaction. Each test was replicated at least six times. Equal distribution of gammarids on the two substrates $(50 \%: 50 \%)$ was recorded as ' $50 \%$ preference'. Deviations from such distributions were registered as preference or avoidance, respectively. The control consisted of stones on both sides of a cage and was analyzed as if the two sides contained different substrates.

\section{Ecologically relevant combinations}

During this experiment other substrate pairings were compared: a) $C$. fluminea shells and sand - to test the effect of another invasive species, b) Chara and sand - to test the effect of $D$. villosus on G. roeselii and hence its occupation of Chara, and c) Chara and stones covered with D. polymorpha - to test the displacement of G. roeselii by D. villosus to Chara.

\section{Abundance loss in enclosures}

Loss of individuals in single and mixed species treatments was calculated as the difference in the number of specimens between start and end of the experiments (after $72 \mathrm{~h}$ ).

\section{Distribution in the field}

We determined the densities of both gammarid species in the littoral zone of Lake Constance in July 2007. We sampled all substrate types used in the enclosure experiments plus one more: stones covered with D. polymorpha, Chara (layer of $50 \mathrm{~mm}$; $55.2 \pm 4.2 \mathrm{~g}$ dry wt.), and sand all located at $1.5-2.5 \mathrm{~m}$ depth in the littoral zone of Egg near the city of Konstanz. Bare stones ( $0.5 \mathrm{~m}$ depth), leaf litter $(0.1-0.5 \mathrm{~m}$ depth), and $250 \mathrm{~mm}$ thick layers of Chara ( $1 \mathrm{~m}$ depth; $194.5 \pm 51.8 \mathrm{~g}$ dry wt.) were taken from a shallow protected bay to the east of Konstanz (Seerhein). We sampled gammarids by snorkeling. A $0.25 \times 0.25 \mathrm{~m}^{2}$ frame of aluminum was placed on the ground from which all substrate was carefully removed into a hand net $(0.2 \mathrm{~mm}$ mesh width). Escaping gammarids were caught with a hand net. All gammarids larger than $3 \mathrm{~mm}$ were fixed in Ethanol $(70 \%)$, counted, and placed into size classes (3-6.9 mm, 7-11.9 mm, >12 mm). Gammarid densities per $\mathrm{m}^{2}$ were calculated. Gammarid counts on C. fluminea were determined at $1 \mathrm{~m}$ depth near Fußach, Austria in the sandy littoral of Lake Constance and were provided by Stefan Werner.

Table 1. Statistical analysis of habitat shift of the gammarid species D. villosus and G. roeselii in the presence of the other species. The gammarids could choose between stones and another substrate. The observed preferences for treatments with single species and experiments with mixed species were compared using a t-test. No p-value was significant after sequential Bonferroni.

\begin{tabular}{lccccccc}
\hline Substrate combinations & \multicolumn{3}{c}{ D. villosus } & & \multicolumn{3}{c}{ G. roeselii } \\
\cline { 2 - 4 } \cline { 6 - 7 } & $\mathbf{t}$ & $\mathbf{n}$ & $\mathbf{p}$ & & $\mathbf{t}$ & $\mathbf{~ n}$ & $\mathbf{p}$ \\
\hline stones vs. stones covered & 1.06 & 6 & 0.316 & & 1.03 & 6 & 0.327 \\
with D. polymorpha & & & & & & \\
stones vs. Chara sp. & 2.16 & 6 & 0.057 & & -1.51 & 6 & 0.162 \\
stones vs. C. fluminea shells & 2.62 & 6 & 0.024 & & -2.53 & 6 & 0.030 \\
stones vs. leaves & -1.70 & 6 & 0.121 & & -0.25 & 4 & 0.811 \\
stones vs. sand & 0.86 & 6 & 0.411 & & -0.008 & 5 & 0.994 \\
\hline
\end{tabular}




\section{Statistical analyses}

All preferences in the enclosures were expressed as the percentage of gammarids collected on one of the two tested substrates. Dead gammarids and individuals found near the dividing zone $( \pm 1 \mathrm{~cm})$ between differing substrates were not included in the analysis. To achieve homogenous variance all percent values in all experiments were angular transformed using $\mathrm{x}^{\prime}=\arcsin$ sqrt $\mathrm{x} ;(0 \leq \mathrm{x} \leq 1)$ for statistical purposes. Homogeneity of variance was checked using a Levene's test. All data was analyzed using Statsoft STATISTICA 6.0 for Windows.

\section{a) Dikerogammarus villosus}

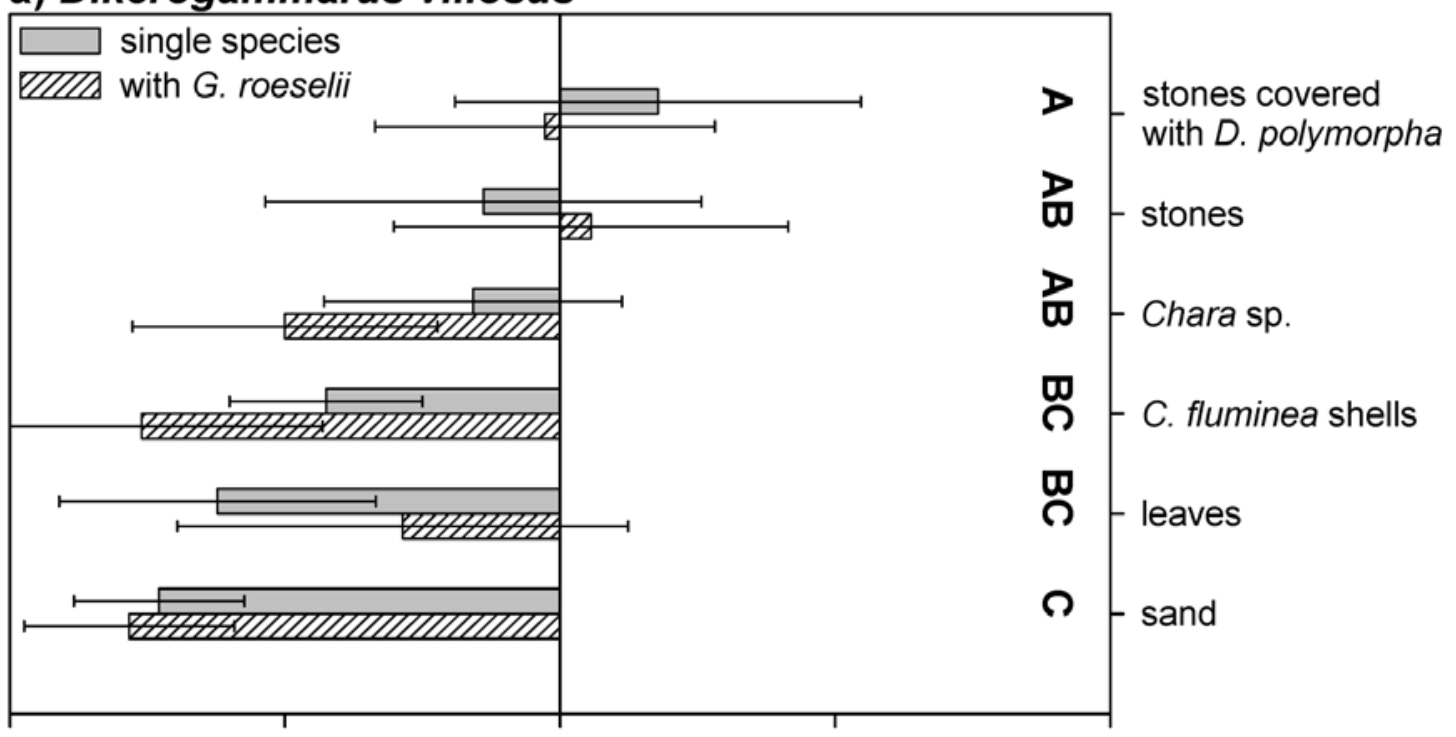

\section{b) Gammarus roeselii}

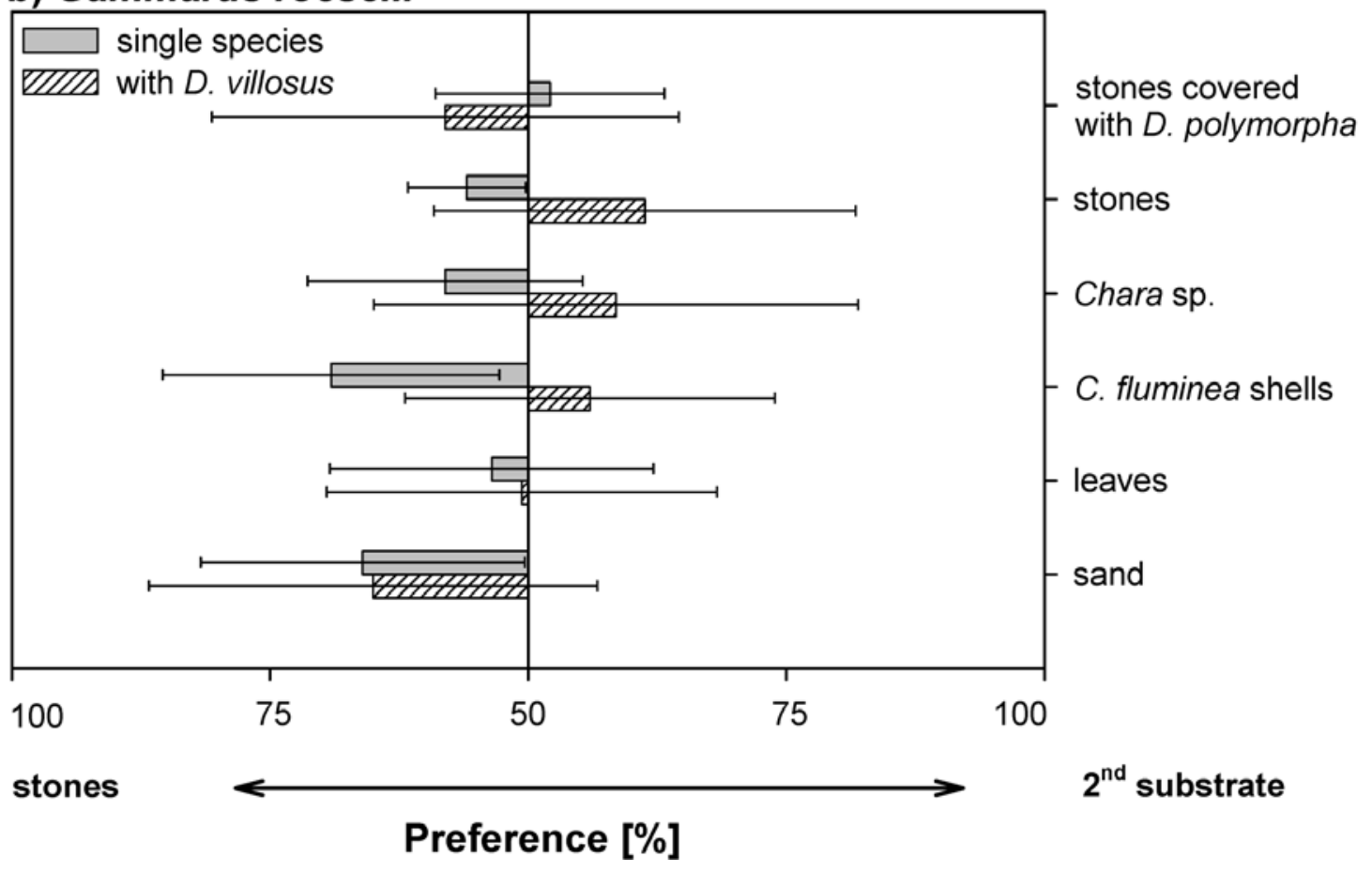

Fig. 1. Habitat choice of a) D. villosus and b) G. roeselii. Enclosure cages contained stones on one side and one of six substrates [stones covered with Dreissena polymorpha, stones (control), Chara sp., Corbicula fluminea shells, leaves, sand] on the other side. The $50 \%$ line indicates an equal distribution between the two substrates offered. Bars indicate a preference for a given substrate. The experiments were conducted with only one species or with both species present, as indicated. A, B, C: significant differences between substrate preferences for single-species experiments (one-way ANOVA with Newman-Keuls post-hoc range test). For statistics regarding habitat shift due to mixed species see Table 1. 


\section{Stones as reference}

To check for equal distribution in controls (stones on both sides) preference for one side was compared with angular transformed equal distribution using a one sample t-test. In the single species treatments preferences for all substrates were compared by using a one-way ANOVA and Newman-Keuls post-hoc range test. Potential habitat shifts due to the presence of the other species were tested for by comparing the preferences between mixed species versus single species experiments using a separate t-test for each substrate. Consequently differences in orientation of habitat shift on discrete substrates could be detected. The level of significance ( $\alpha=0.05$ ) for the t-tests was adjusted for by applying sequential Bonferroni correction to all substrates.

\section{Ecologically relevant combinations}

The preference for one out of two substrates per combination was compared with angular transformed equal distribution using a one sample t-test. Using ANOVA was not possible due to the lack of a reference substrate. Potential habitat shifts were analyzed as described above. The significance levels for both analyses $(\alpha=0.05)$ were adjusted using a sequential Bonferroni correction for the three substrate combinations.

\section{Abundance loss in enclosures}

To determine predation between the gammarid species the percent specific loss rates of single and mixed species treatments were compared using a separate t-test for each of the two gammarid species. When a higher loss occurred due to the presence of the other species the influence of substrate was evaluated using a one-way ANOVA.

\section{Distribution in the field}

Because G. roeselii is generally smaller than D. villosus the statistical comparison of the size class distribution is not reasonable. Instead total densities of both species on the different substrates were analyzed. Densities were transformed using $\mathrm{x}^{\prime}=\mathrm{x}^{\wedge} 0.4$ to obtain homogenous variances. Both species were analyzed separately. Densities on all substrates were compared using one-way ANOVA and Newman-Keuls post-hoc range test.

\section{Results}

\section{Substrate preference enclosure experiments}

\section{Stones as reference}

All controls (stones on both sides) were equally distributed (D. villosus alone: $\mathrm{p}=0.377, \mathrm{t}=-0.954$, mixed species: $\mathrm{p}=0.982, \mathrm{t}=0.024 ; G$. roeselii alone: $\mathrm{p}=0.229, \mathrm{t}=-1.339$, mixed species: $\mathrm{p}=0.197$, $\mathrm{t}=1.453 ; \mathrm{df}=5$, one sample $\mathrm{t}$-test).

D. villosus clearly revealed substrate choice $(\mathrm{p}<0.001, \mathrm{~F}=8.267, \mathrm{df}=5$, one-way ANOVA, Fig. 1a). As a single species D. villosus preferred stones (with and without D. polymorpha) and Chara over shells of
C. fluminea, leaves, and sand (Newman-Keuls range post hoc test). Pure sand was the least preferred substrate. Those individuals present in the sand compartment were located in corners on gauze. Conversely, G. roeselii seemed preferentially indifferent to substrate $(\mathrm{p}=0.290, \mathrm{~F}=1.305, \mathrm{df}=5$, one-way ANOVA; Fig. 1b). Individuals of $G$. roeselii were even found on the surface and burrowing into the sand. Neither species showed a significant shift in substrate preference in the presence of the other species (Table 1).

\section{Ecologically relevant combinations}

$D$. villosus significantly preferred $D$. polymorpha over Chara (Fig. 2a, Table 2) as an alternative substrate preference. The preference for Chara when compared with sand was not significant due to sequential Bonferroni correction (Fig. 2a, Table 2). In the presence of G. roeselii, D. villosus preferred C.fluminea over sand. Additionally, its preference for D. polymorpha over Chara vanished (Fig. 2a, Table 2). G. roeselii remained indifferent to substrate choice both in the presence and absence of D. villosus (Fig. 2b, Table 2).

\section{Abundance loss in enclosures}

There was a mean loss of $13.0 \%$ for D. villosus and $16.3 \%$ for $G$. roeselii during the single species experiments. Gammarid loss resulted from predation, natural mortality, and handling effects. In mixed species experiments loss of $D$. villosus did not differ from single species experiments $(13.5 \% ; \mathrm{p}=0.613, \mathrm{t}=0.507$, $\mathrm{n}=56$, t-test), whereas the loss of $G$. roeselii rose significantly to $26.7 \%(\mathrm{p}<0.001, \mathrm{t}=3.655, \mathrm{n}=56$, $\mathrm{t}$ test). This enhanced loss rate could not be associated with differing combinations in substrate $(\mathrm{p}=0.308$, $\mathrm{F}=1.221, \mathrm{df}=8$, one-way ANOVA).

\section{Distribution in the field}

In the field both species revealed different distributions on the analyzed substrates $(D$. villosus: $\mathrm{p}<0.001$, $\mathrm{F}=9.812 ;$ G. roeselii: $\mathrm{p}<0.001, \mathrm{~F}=74.42 ; \mathrm{df}=6$, oneway ANOVA). D. villosus preferred stones (with or without D. polymorpha) and the 5-cm layer of Chara and was rare or absent on shells of $C$. fluminea, leaf litter and sand. Its densities in the thick layer of Chara were intermediate (Fig. 3a; Newman-Keuls range post hoc test). G. roeselii appeared in high densities in the $25 \mathrm{~cm}$ layer of Chara and in leaf litter. Densities in the thin layer of Chara were intermediate, and low on stones (with or without D. polymorpha), shells of C. fluminea and on sand (Fig. 3b; Newman-Keuls 


\section{a) Dikerogammarus villosus}

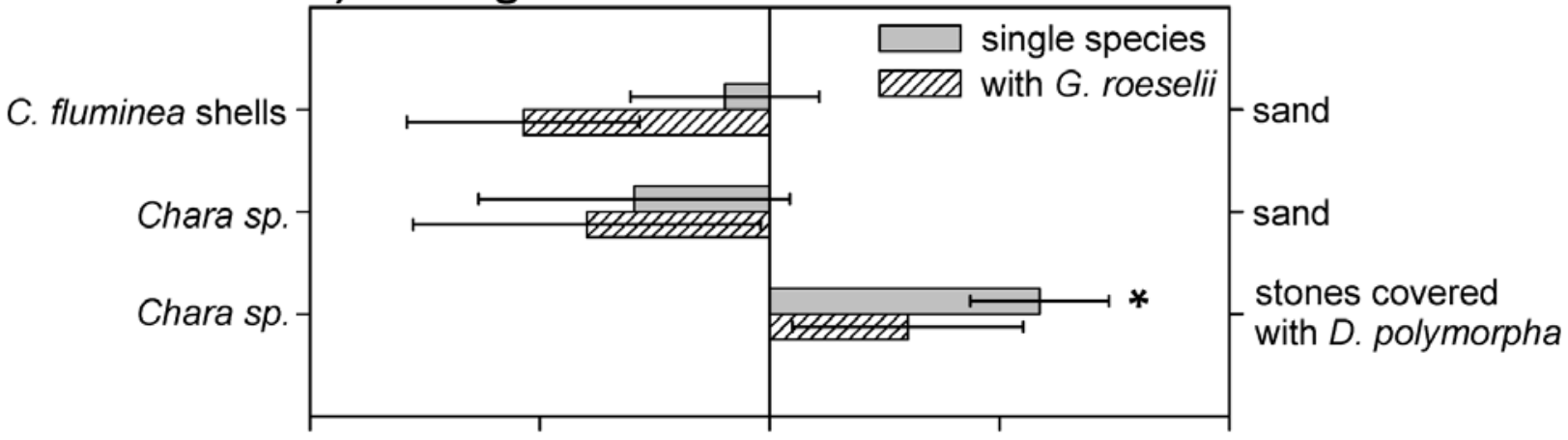

\section{b) Gammarus roeselii}

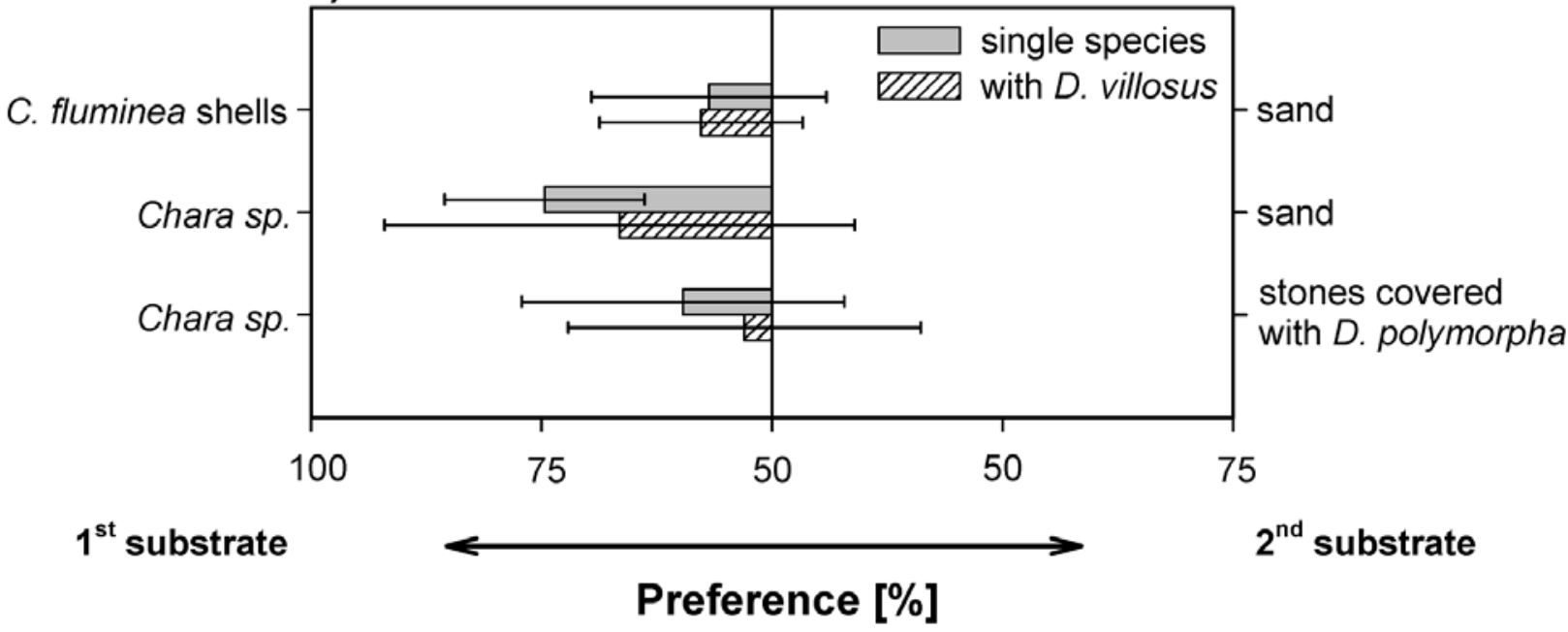

Fig. 2. Habitat choice of a) D. villosus and b) G. roeselii. Enclosure cages contained the substrate combinations indicated. The experiments were conducted with only one species or with both species, as indicated. *: preference for one of the substrates in single-species experiments (t-test, $\mathrm{p}<0.001$; significance after sequential Bonferroni correction).

Table 2. Statistical analysis of substrate choice (additional combinations) of D. villosus and G. roeselii. Preferences between one of the two alternative substrates for every combination in single species experiments were compared using one sample t-test against equal distribution. Positive t-values indicate more individuals chose the second substrate. For habitat shift due to the presence of the other species the observed preferences from single species and mixed species treatments were compared with t-test. Values in bold: significant after sequential Bonferroni correction.

\begin{tabular}{|c|c|c|c|c|c|c|c|c|c|c|c|c|}
\hline \multirow[t]{3}{*}{ Substrate combination } & \multicolumn{6}{|c|}{ D. villosus } & \multicolumn{6}{|c|}{ G. roeselii } \\
\hline & \multicolumn{3}{|c|}{ Preference } & \multicolumn{3}{|c|}{ Habitat shift } & \multicolumn{3}{|c|}{ Preference } & \multicolumn{3}{|c|}{ Habitat shift } \\
\hline & $\mathbf{t}$ & $\mathbf{n}$ & $\mathbf{p}$ & $\mathbf{t}$ & $\mathbf{n}$ & p & $\mathbf{t}$ & $\mathbf{n}$ & $\mathbf{p}$ & $\mathbf{t}$ & $\mathbf{n}$ & $\mathbf{p}$ \\
\hline C. fluminea shells vs. sand & -1.17 & 6 & 0.296 & -3.26 & 6 & 0.008 & -1.32 & 6 & 0.245 & -0.13 & 6 & 0.902 \\
\hline Chara sp. vs. sand & -2.25 & 8 & 0.058 & -0.44 & 7 & 0.669 & -3.91 & 4 & 0.029 & 0.10 & 4 & 0.925 \\
\hline $\begin{array}{l}\text { Chara sp. vs. stones covered } \\
\text { with } D \text {. polymorpha }\end{array}$ & -7.92 & 5 & 0.001 & 2.34 & 6 & 0.004 & 1.34 & 6 & 0.237 & -0.64 & 6 & 0.553 \\
\hline
\end{tabular}

range post hoc test). Overall the densities of G. roeselii appear to be higher than those for D. villosus, but substrates with the highest densities of G. roeselii (thick layers of Chara and long lasting patches of leaf litter) are very rare, whereas stones, sand and thin layers of Chara are very common in the lake. 
a) D. villosus

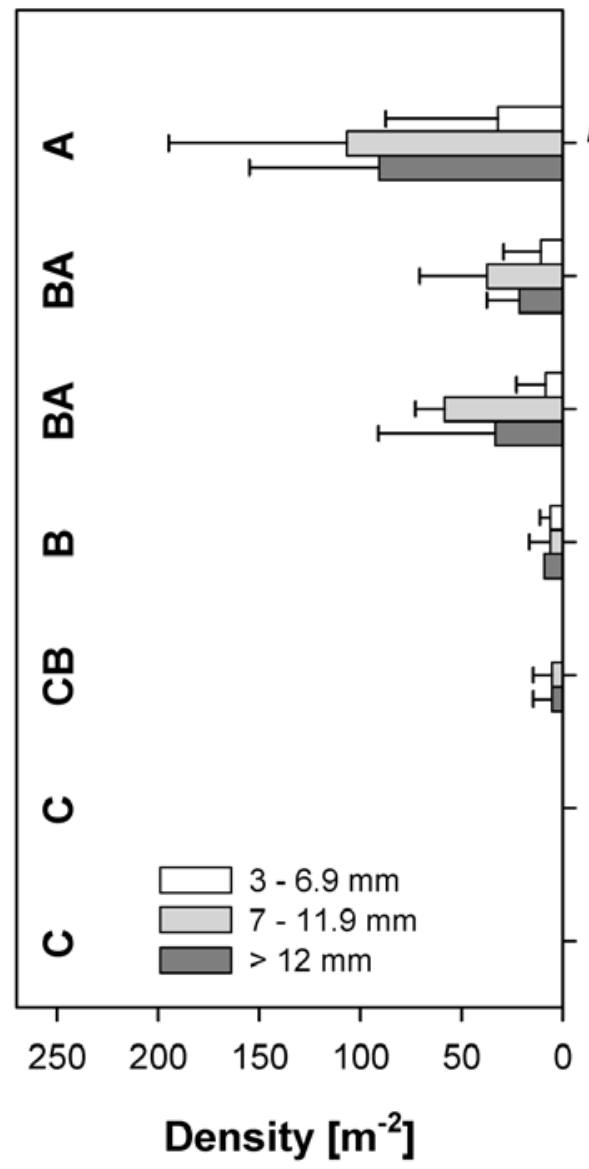

Substratum

b) G. roeselii

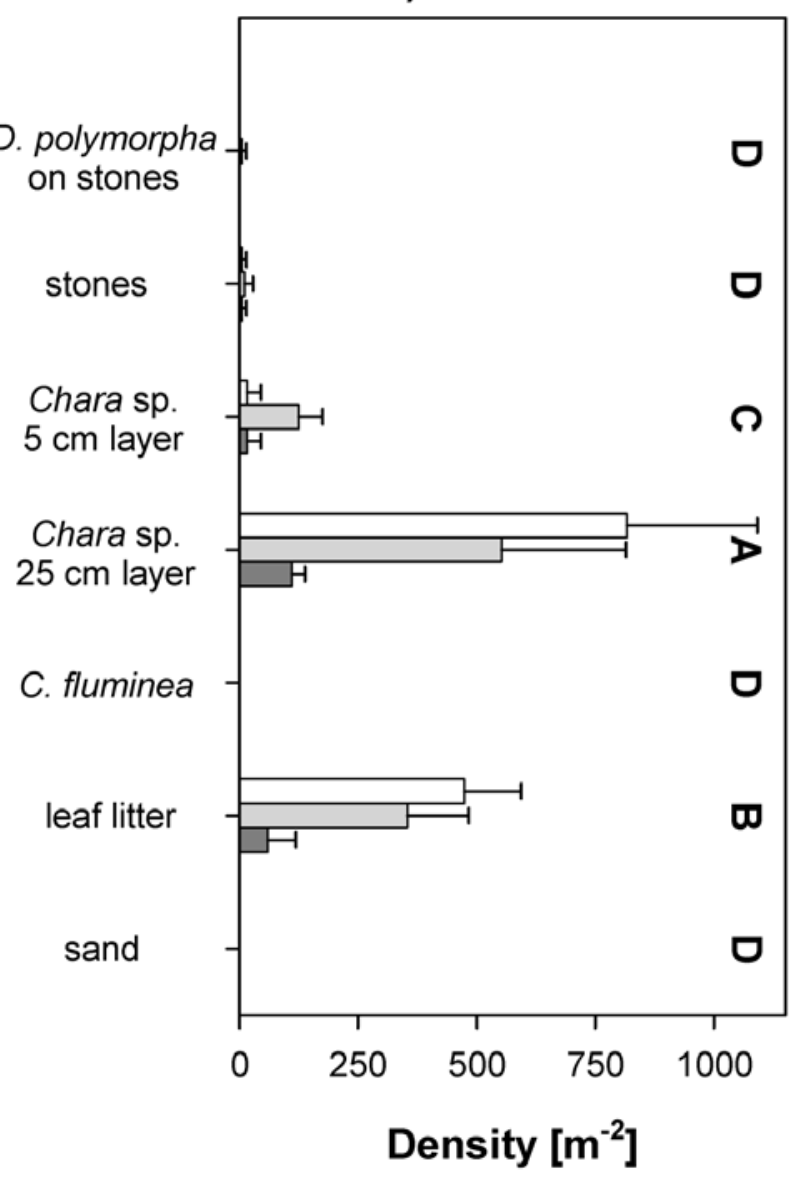

Fig. 3. Distribution of a) D. villosus and b) G. roeselii in the littoral zone of Lake Constance. Densities were obtained for several size classes, as indicated. A, B, C, D: significant differences between total densities on the indicated substrates (one-way ANOVA with Newman-Keuls post-hoc range test).

\section{Discussion}

\section{Enclosure experiments}

In our enclosures, D. villosus clearly portrayed substrate choice. It preferred stony substrates, especially when covered with D. polymorpha, and simultaneously avoided bare sand and leaf litter. In contrast, G. roeselii revealed no significant selective capacity.

To our knowledge only one published experimental study analyzing substrate preferences of $D$. villosus (van Riel et al. 2007) exists. The authors concluded that $D$. villosus prefers small lava stones to bigger ones and avoids sand, and that G. roeselii revealed weaker preferences. These results were confirmed by our findings as well. Because other substrates, especially organic materials, were not analyzed in that study we will continue discussing our results using published field data.
Reports from Lake Balaton observed D. villosus primarily on groyne stones overgrown with $D$. polymorpha and in lower densities on macrophytes (Musko 1989). In rivers D. villosus occurs in areas of low habitat diversity due to channelization. For example, in the French River Moselle and in modified distributaries of the River Rhine in the Netherlands high densities of D. villosus are found on riverbanks consisting of groyne stones (Devin et al. 2003, van Riel et al. 2006). There $D$. villosus is strongly associated with $D$. polymorpha and is never found on sand. In contrast, G. roeselii can be found on a wide variety of substrates such as in leaf litter and on plants, as revealed by our field data (Mörtl et al. 2005). In Lake Constance G. roeselii formerly occupied stony substrates in high densities which are now the preferred habitats of $D$. villosus (Mörtl et al. 2005).

A deeper insight into the selective capacity of D. villosus is provided by the analysis of further eco- 
logically relevant substrate combinations in the enclosures. D. polymorpha is highly preferred to Chara, which was not clearly shown in the previous experiment. This preference can be explained by a strong association between the invasive gammarid and zebra mussels as discussed by Lods-Crozet \& Reymond (2006). G. roeselii did not show a significant disparity in distribution to D. villosus as it did in the previous experiment. The presence of G. roeselii accounts for two shifts in the choice behavior of D. villosus: First, the preference towards D.polymorpha compared to Chara was significantly reduced. In the mixed species treatment $G$. roeselii was essentially equally distributed over both substrates. Because it serves as a food source for D. villosus (Dick et al. 2002, Kinzler $\&$ Maier 2003) the invader probably followed its prey into the Chara. The second change in choice of $D$. villosus is seen by avoidance of pure sand in contrast to shells of C. fluminea. This behavior supports the results of the previous experiment and is also described by Werner \& Rothhaupt (2008). We have no explanation for the lack of this effect in the single species treatment.

Most probably we could observe predation by D. villosus on G.roeselii during our experiments. There was a significant increase in G. roeselii mortality in mixed species treatments compared with single species treatments. The most important mechanism for the successful invasion of $D$. villosus is direct predation of other gammarids as discussed by Dick et. al (2002) and Kinzler \& Maier (2003). In sight of such predation we anticipated avoidance behavior by $G$. roeselii in the presence of D. villosus in mixed species treatments, something we did not observe. G. roeselii had ample opportunity to avoid areas of exposure to the invader until after the end of the experiment (after $72 \mathrm{~h}$ ), hence we presume that $G$. roeselii does not actively avoid areas populated by D. villosus, but rather survives in habitats avoided by the invader.

Overall, G. roeselii exhibited no habitat preference, either alone or in the presence of D. villosus, whereas D. villosus revealed several substrate preferences. We therefore conclude that $G$. roeselii displays much weaker substrate choice behavior than D. villosus does. This presents $G$. roeselii with a wider spectrum of possible habitats.

\section{Field data}

Field distributions of $D$. villosus during the summer 2007 mainly correspond with the results obtained from the enclosure experiments. However, their density on shells of $C$. fluminea was surprisingly low. This can be explained as follows: 1) most shells in the field are buried in the sediment and 2) until now $C$. fluminea is only found in specific locations surrounded by large areas of pure sand which are avoided by D. villosus. In contrast, the field distribution of $G$. roeselii is rapidly shifting towards characeans and leaf litter when compared to G. roeselii populations in the enclosure experiment. These differences reveal deeper insight into the displacement of G. roeselii by D. villosus, since $G$. roeselii formerly occurred in very high densities on stones with and without D. polymorpha (Mörtl et al. 2005). Therefore our findings in the field do not contradict our results in the enclosure experiment, in fact they support displacement of the native by the invasive gammarid. It is now obvious that we mainly find $G$. roeselii on substrates not inhabited by D. villosus. The mean densities of both species in the 50-mm layer of Chara hint towards alternative mechanisms of coexistence which have yet to be analyzed in future studies. The absence of G. roeselii and D. villosus on wide sandy surfaces in the field is not surprising, because these areas are devoid of food sources such as leaf litter and prey organisms. G. roeselii can be observed on sand in the field in the vicinity of hard substrate. Many recent publications discuss the predominant predatory feeding of D. villosus (Dick et al. 2002, Krisp \& Maier 2005). Its absence in leaf litter in our field survey supports this hypothesis.

Our data revealed coexistence between $D$. villosus and G. roeselii in Lake Constance since the invasion of D. villosus in 2003. These findings are contradictory to other studies that showed complete replacement of native gammarids (e.g. Devin et al. 2003, Dick \& Platvoet 2000). Areas devoid of gammarid coexistence consist of mechanically manipulated rivers and lakes where high habitat diversity and structure rich organic substrates such as characeans and leaf litter are rare or missing. For example, the hard substrate coast of Lake Balaton where G. roeselii was displaced by Dikerogammarus spp. consists predominantly of hard man-made substrate in the form of groyne stones. Additionally, in the whole lake characeans suffered a die-back between 1940 and 1960 (Musko 1994, Virág 1998). We hypothesize that nearly natural or variable structured waterbodies like Lake Constance can provide coexistence between $D$. villosus and $G$. roeselii as well as other indigenous gammarid species with varied substrate preferences.

In conclusion, we acknowledge that $G$. roeselii is being reduced by the invasive $D$. villosus in most parts of Lake Constance. However, owing to the strong pref- 
erence of $D$. villosus for stony substrates, especially when covered with D.polymorpha, there appears to be hope for G.roeselii. We anticipate that G. roeselii will survive on alternative substrates: (1) leaf litter: This substrate was not inhabited by D. villosus, but sustained high densities of G. roeselii. Since leaf patches are seasonally or locally restricted to depositional sites along the littoral zone of the lake, they will only support a small part of the G. roeselii population. (2) Chara: In the field we found both gammarid species in patches of Chara, and consistent with this, both species used this substrate in our enclosure experiments. The underlying mechanisms behind these observations require further studies. We presume that these structure-rich macroalgae are important for the survival of G. roeselii, especially since characeans have been spreading rapidly in the littoral zone over the last years due to reoligotrophication (Schmieder et al. 2006). Additional studies concerning e.g. effects of predation and interactions with other invaders are essential for a better understanding of the affects of D. villosus on the native or well-established gammarid communities in Europe.

\section{Acknowledgements}

This work was supported by the Sonderforschungsbereich Bodenseelitoral (CRC 454) of the Deutsche Forschungsgemeinschaft. Field densities of the gammarids on shells of $C$. fluminea in the bay of Fussach were kindly provided by Stefan Werner. The authors want to thank Karl-Otto Rothhaupt, Stefan Werner and all members of the ANEBO group for fruitful discussions on the recent invaders in Lake Constance. We thank Karen A. Brune and Sonja Raub for editing the manuscript.

\section{References}

Bij de Vaate, A. B., Jazdzewski, K., Ketelaars, H. A. M., Gollasch, S. \& van der Velde, G., 2002: Geographical patterns in range extension of Ponto-Caspian macroinvertebrate species in Europe. - Can. J. Fish. Aquat. Sci. 59: 1159-1174.

Bollache, L., 2004: Dikerogammarus villosus (Crustacea: Amphipoda): another invasive species in Lake Geneva. - Rev. Suisse Zool. 111: 309-313.

Bollache, L., Devin, S., Wattier, R., Chovet, M., Beisel, J. N., Moreteau, J. C. \& Rigaud, T., 2004: Rapid range extension of the Ponto-Caspian amphipod Dikerogammarus villosus in France: potential consequences. - Arch. Hydrobiol. 160: 57-66.

Bruijs, M. C. M., Kelleher, B., van der Velde, G. \& Bij de Vaate, A., 2001: Oxygen consumption, temperature and salinity tolerance of the invasive amphipod Dikerogammarus villosus: indicators of further dispersal via ballast water transport. Arch. Hydrobiol. 152: 633-646.

Casellato, S., La Piana, G., Latella, L. \& Ruffo, S., 2006: Dikerogammarus villosus (Sowinsky, 1894) (Crustacea, Amphipoda, Gammaridae) for the first time in Italy. - Ital. J. Zool. 73: 97-104.
Devin, S. \& Beisel, J. N., 2007: Biological and ecological characteristics of invasive species: a gammarid study. - Biol. Invasions 9: 13-24.

Devin, S., Beisel, J. N., Bachmann, V. \& Moreteau, J. C., 2001: Dikerogammarus villosus (Amphipoda: Gammaridae): another invasive species newly established in the Moselle river and French hydrosystems. - Ann. Limnol. - Internat. J. Limnol. 37: 21-27.

Devin, S., Piscart, C., Beisel, J. N. \& Moreteau, J. C., 2003: Ecological traits of the amphipod invader Dikerogammarus villosus on a mesohabitat scale. - Arch. Hydrobiol. 158: 43-56.

Devin, S., Piscart, C., Beisel, J. N. \& Moreteau, J. C., 2004: Life history traits of the invader Dikerogammarus villosus (Crustacea: Amphipoda) in the Moselle River, France. - Internat. Rev. Hydrobiol. 89: 21-34.

Dick, J. T. A., Irvine, D. E. \& Elwood, R. W., 1990: Differential predation by males on molted females may explain the competitive displacement of Gammarus duebeni by G. pulex (Amphipoda). - Behavioral Ecol. Sociobiol. 26: 41-45.

Dick, J. T. A. \& Platvoet, D., 2000: Invading predatory crustacean Dikerogammarus villosus eliminates both native and exotic species. - Proc. Roy. Soc. London Ser. B - Biol. Sci. 267: 977-983.

Dick, J. T. A., Platvoet, D. \& Kelly, D. W., 2002: Predatory impact of the freshwater invader Dikerogammarus villosus (Crustacea: Amphipoda). - Can. J. Fish. Aquat. Sci. 59: 1078-1084.

Gervais, M., 1835: Note sur deux espèces de Crevettes qui vivent aux environs de Paris. - Ann. Sci. Naturelles 2: 127-128

Grabowski, M., Bacela, K. \& Konopacka, A., 2007a: How to be an invasive gammarid (Amphipoda: Gammaroidea) - comparison of life history traits. - Hydrobiologia 590: 75-84.

Grabowski, M., Jazdzewski, K. \& Konopacka, A., 2007b: Alien Crustacea in Polish waters - Amphipoda. - Aquat. Invasions 2: 25-38.

Gross, E. M., Feldbaum, C. \& Choi, C., 2002: High abundance of herbivorous Lepidoptera larvae (Acentria ephemerella Denis \& Schiffermüller) on submersed macrophytes in Lake Constance (Germany). - Arch. Hydrobiol. 155: 1-21.

Haas, G., Brunke, M. \& Streit, B., 2002: Fast turnover on dominance of exotic species in the Rhine River determines the biodiversity and ecosystem function: an affair between amphipods and mussels. - In: Leppäskoski, E., Gollasch, S. \& Olenin, S. (eds): Invasive aquatic species of Europe. - Kluwer, the Netherlands, pp. 426-432.

Jazdzewski, K., 1980: Range extension of some gammaridean species in European inland waters caused by human activity. - Crustaceana Suppl. 6: 84-107.

Josens, G., Bij de Vaate, A., Usseglio-Polatera, P., Cammaerts, R., Cherot, F., Grisez, F., Verboonen, P. \& Bossche, J. P. V., 2005: Native and exotic Amphipoda and other Peracarida in the River Meuse: new assemblages emerge from a fast changing fauna. - Hydrobiologia 542: 203-220.

Kelleher, B., Bergers, P. J. M., van den Brink, F. W. B., Giller, P. S., van der Velde, G. \& Bij de Vaate, A., 1998: Effects of exotic amphipod invasions on fish diet in the Lower Rhine. Arch. Hydrobiol. 143: 363-382.

Kinzelbach, R., 1995: Neozoans in European waters - exemplifying the worldwide process of invasion and species mixing. - Experientia 51: 526-538. 
Kinzler, W. \& Maier, G., 2003: Asymmetry in mutual predation: possible reason for the replacement of native gammarids by invasives. - Arch. Hydrobiol. 157: 473-481.

Krisp, H. \& Maier, G., 2005: Consumption of macroinvertebrates by invasive and native gammarids: a comparison. - J. Limnol. 64: 55-59.

Lods-Crozet, B. \& Reymond, O., 2006: Bathymetric expansion of an invasive gammarid (Dikerogammarus villosus, Crustacea, Amphipoda) in Lake Léman. - J. Limnol. 65: 141-144.

MacNeil, C., Dick, J. T. A., Elwood, R. W. \& Montgomery, W. I., 2001: Coexistence among native and introduced freshwater amphipods (Crustacea); habitat utilization patterns in littoral habitats. - Arch. Hydrobiol. 151: 591-607.

MacNeil, C. \& Platvoet, D., 2005: The predatory impact of the freshwater invader Dikerogammarus villosus on native Gammarus pulex (Crustacea: Amphipoda); influences of differential microdistribution and food resources. - J. Zool. 267: 31-38.

Mörtl, M., Mürle, U., Ortlepp, J., Rey, P., Scheifhacken, N. \& Werner, S., 2005: Dikerogammarus villosus (Crustacea: Amphipoda) und Corbicula fluminea (Bivalvia: Veneroidea) im Bodensee. - Institut für Seenforschung 5: 15-30.

Mörtl, M. \& Rothhaupt, K. O., 2003: Effects of adult Dreissena polymorpha on settling juveniles and associated macroinvertebrates. - Internat. Rev. Hydrobiol. 88: 561-569.

Mürle, U., Becker, A. \& Rey, P., 2004: Dikerogammarus villosus (Amphipoda) im Bodensee. - Lauterbornia 49: 77-80.

Musko, I. B., 1989: Amphipoda (Crustacea) in the littoral-zone of Lake Balaton (Hungary) - qualitative and quantitative Studies. - Internat. Rev. ges. Hydrobiol. 74: 195-205.

- 1994: Occurrence of Amphipoda in Hungary since 1853. Crustaceana 66: 144-152.

Pabst, S., Scheifhacken, N., Hesselschwerdt, J. \& Wantzen, K. M., 2008: Leaf litter degredation in the wave impact zone of a pre-alpine lake. - Hydrobiologia 613: 117-131.

Pöckl, M., 2007: Strategies of a successful new invader in European fresh waters: fecundity and reproductive potential of the Ponto-Caspian amphipod Dikerogammarus villosus in the Austrian Danube, compared with the indigenous Gammarus fossarum and G. roeseli. - Freshwat. Biol. 52: 50-63.

Sala, O. E., Chapin, F. S., Armesto, J. J., Berlow, E., Bloomfield, J., Dirzo, R., Huber-Sanwald, E., Huenneke, L. F., Jackson, R. B., Kinzig, A., Leemans, R., Lodge, D. M.,
Mooney, H. A., Oesterheld, M., Poff, N. L., Sykes, M. T., Walker, B. H., Walker, M. \& Wall, D. H., 2000: Biodiversity - Global biodiversity scenarios for the year 2100. - Science 287: 1770-1774.

Schmieder, K., Schünemann, B. \& Schröder, H. G., 2004: Spatial patterns of surface sediment variables in the littoral zone of Lake Constance (Germany). - Arch. Hydrobiol. 161: 455-468.

Schmieder, K., Werner, S. \& Bauer, H. G., 2006: Submersed macrophytes as a food source for wintering waterbirds at Lake Constance. - Aquat. Bot. 84: 245-250.

Tittizer, T., Schöll, F., Banning, M., Haybach, A. \& Schleuter, M., 2000: Aquatische Neozoen im Makrozoobenthos der Bundeswasserstraßen Deutschlands. - Lauterbornia 39: $1-72$.

Uehlinger, U., Wantzen, K. M., Leuven, R. \& Arndt, H., in press: Rhine River basin. - In: Tockner, K., Uehlinger, U. \& Robinson, C. (eds): The Rivers of Europe. - Elsevier, London.

van Riel, M. C., Healy, E. P., van der Velde, G. \& Bij de Vaate, A., 2007: Interference competition among native and invader amphipods. - Acta Oecol. - Internat. J. Ecol. 31: 282-289.

van Riel, M. C., van der Velde, G., Rajagopal, S., Marguillier, S., Dehairs, F. \& Bij de Vaate, A., 2006: Trophic relationships in the Rhine food web during invasion and after establishment of the Ponto-Caspian invader Dikerogammarus villosus. - Hydrobiologia 565: 39-58.

Virág Á., 1998: A Balaton algaflórája. - In: Virág, Á. (ed.): A Balaton múltja és jelene. - Egri Nyomda, Eger, pp. 520 547.

Werner, S. \& Rothhaupt, K. O., 2008: Detecting effects of the invasive Asian clam Corbicula on benthic macroinvertebrate taxa in laboratory experiments. - Fundam. Appl. Limnol., Arch. Hydrobiol. 173: 145-152.

Wijnhoven, S., van Riel, M. C. \& van der Velde, G., 2003: Exotic and indigenous freshwater gammarid species: physiological tolerance to water temperature in relation to ionic content of the water. - Aquat. Ecol. 37: 151-158.

Zytkowicz, J., Kobak, J., Kakareko, T. \& Kentzer, A., 2008: Species composition and distribution of invasive Ponto-Caspian amphipods in the off-channel microhabitats of a temperate, lowland dam reservoir. - Internat. Rev. Hydrobiol. 93: 62-72. 